\title{
ФОРМИ ДІЯЛЬНОСТІ НАЦІОНАЛЬНОЇ ПОЛІЦІЇ УКРАЇНИ ЩОДО ПРОТИДІЇ НЕЗАКОННОМУ ОБІГУ НАРКОТИЧНИХ ЗАСОБІВ, ПСИХОТРОПНИХ РЕЧОВИН I ПРЕКУРСОРІВ
}

Ярмакі Х. П., Тригуб С. М.

Незаконний обіг наркотиків і зловживання ними продовжують розвиватися з наростаючими темпами, представляючи реальну загрозу національній безпеці України. Наркоманія, як результат незаконного обігу наркотичних засобів, психотропних речовин та прекурсорів, виявляє руйнівний вплив на соціально-економічний стан країни, на духовне життя суспільства, на генофонд народу, сприяє поширенню смертельно небезпечних захворювань, призводить до збільшення кількості правопорушень, пов'язаних з наркоманією та наркобізнесом.

Наукові дослідження, присвячені питанням забезпечення протидіі незаконному обігу наркотичних засобів, психотропних речовин і прекурсорів та подоланню наркоманії в Україні, дотепер не втрачають своєі актуальності. Це зумовлено тим фактором, що підвищення рівня та динаміки зловживання наркотичними засобами, психотропними речовинами і прекурсорами та їх незаконне розповсюдження в українському контексті є вагомою перепоною на шляху втілення правової парадигми. В статmі проаналізовано терміни «форма» та «форма діяльності», надані їх ознаки та визначено особливості в контексті теми наукового дослідження діяльності Національної поліції України щодо протидії незаконному обігу наркотичних засобів, психотропних речовин і прекурсорів.

До загальних ознак форм діяльності Національної поліції України щодо протидії незаконному обігу наркотичних засобів, психотропних речовин і прекурсорів автором віднесено: а) зовнішнє відображення дій органів Національної поліціі України; б) реалізація в межах компетенції поліції; в) закріпленість у нормативно-правових актах; г) спрямованість на попередження і усунення негативних чинників, що ускладнюють їх реалізацію.

Запропоновано наступне трактування форм діяльності в галузі, що аналізується: форми діяльності Національної поліції України щодо протидії незаконному обігу наркотичних засобів, nсuхотропних речовин і прекурсорів - це зовнішнє вираження дій Національної поліції України в межах своєї компетенції з питань реалізації завдань і функцій в галузі обігу наркотичних засобів, психотропних речовин і прекур-

() Ярмакі Х. П., Тригуб С. М., 2020 сорів, спрямованих на попередження і усунення негативних чинників, що ускладнюють їх реалізацію.

здійснено класифікацію форм діяльності органів влади у сфері протидії незаконному обігу наркотичних засобів, психотропних речовин і прекурсорів за ступенем правової регламентації на правові та організаційні форми діяльності. Встановлено, що правові форми виявляються під час реалізачії таких функцій, як виявлення та розгляд правопорушень у сфері незаконного обігу наркотичних засобів, психотропних речовин і прекурсорів; проведення рейдів та перевірок; проведення спеціальних заходів, спрямованих на попередження, виявлення та розкриття правопорушень, затримання винних осіб та притягнення їх до відповідальності тощо. Підкреслено, що окремим видом діяльності в межах виділеної групи є контрольно-наглядова діяльність поліції, яка у сфері протидіі незаконному обігу наркотичних засобів, ncuxоmponних речовин і прекурсорів має певні особливості.

Крім правової форми діяльності поліції $\epsilon$ і організаційна форма, яка не потребує повного й суворого юридичного оформлення, не пов'язана з виконанням юридично значущих дій, тобто не тягне за собою правових наслідків.

Розкрито характеристики правових та організаційних форм діяльності.

Визначення форм діяльності Національної поліції в цій галузі дає можливість належним чином зосередити увагу на проблемі протидії незаконного обігу наркотичних засобів, психотропних речовин та прекурсорів не тільки спеціальних суб'єктів, але й громадськості.

Ключові слова: форми діяльності, поліція, протидія, незаконний обіг, наркотичні засоби, психотропні речовини та прекурсори.

Yarmaki K. P., Tryhub S. M. Forms of activity of the National Police of Ukraine on counteraction to illicit trafficking in narcotic drugs, psychotropic substances and precursors

Drug trafficking and abuse continue to grow at an increasing rate, posing a real threat to Ukraine's national security. Drug addiction, as a result of illicit trafficking in narcotic drugs, psychotropic substances and precursors, has a devastating effect on the 
socio-economic state of the country, on the spiritual life of society, on the gene pool of the people, contributes to the spread of deadly diseases, increases drug offenses drug business.

Scientific research on combating the illicit trafficking of narcotic drugs, psychotropic substances and precursors and overcoming drug addiction in Ukraine has not lost its relevance to date. This is due to the fact that increasing the level and dynamics of abuse of narcotic drugs, psychotropic substances and precursors and their illegal distribution in the Ukrainian context is a significant obstacle to the implementation of the legal paradigm. The article analyzes the terms "form" and "form of activity", provides their features and identifies features in the context of the research of the National Police of Ukraine on combating illicit trafficking in narcotic drugs, psychotropic substances and precursors.

The general features of the forms of activity of the National Police of Ukraine in combating illicit trafficking in narcotic drugs, psychotropic substances and precursors include: a) external reflection of the actions of the National Police of Ukraine; b) implementation within the competence of the police; c) enshrined in regulations; d) focus on prevention and elimination of negative factors that complicate their implementation.

The following interpretation of forms of activity in the analyzed area is offered: forms of activityof the National Police of Ukraine on counteraction to illicit trafficking in narcotic drugs, psychotropic substances and precursors is an external expression of actions of the National Police of Ukraine, within the limits of the competence. drugs, psychotropic substances and precursors aimed at preventing and eliminating the negative factors that complicate their implementation.

The classification of forms of activity of authorities in the field of combating illicit trafficking in narcotic drugs, psychotropic substances and precursors according to the degree of legal regulation on legal and organizational forms of activity is carried out. It is established that legal forms are revealed during the implementation of such functions as detection and consideration of offenses in the field of illicit trafficking in narcotic drugs, psychotropic substances and precursors; conducting raids and inspections; carrying out special measures aimed at preventing, detecting and disclosing offenses, detaining guilty persons and bringing them to justice, etc. It is emphasized that a separate type of activity within the selected group is the control and supervision activities of the police, which in the field of combating illicit trafficking in narcotic drugs, psychotropic substances and precursors has certain features.

In addition to the legal forms of police activity, there is also an organizational form that does not require full and strict legal registration, is not related to the implementation of legally significant actions, ie does not entail legal consequences.
The characteristics of legal and organizational forms of activity are revealed.

Defining the forms of activity of the National Police in this area makes it possible to properly focus attention on the problem of combating illicit trafficking in narcotic drugs, psychotropic substances and precursors not only of special entities, but also of the public.

Key words: forms of activity, police, counteraction, illegal traffic, narcotic drugs, psychotropic substances and precursors.

Постановка проблеми. Побудова правової, демократичної, соціальної держави, що закріплено нормами Конституції України, вимагає неухильного дотримання державними органами та їх посадовими особами прав, свобод та інтересів людини, забезпечення законності у сфері обігу наркотичних засобів, психотропних речовин i прекурсорів. Поширення наркоманії, як у світі загалом, так і в Україні зокрема, є однією з найгостріших суспільних проблем, нерозв'язання якої призводить до заподіяння шкоди життю та здоров'ю людини. Протидія незаконному обігу наркотичних засобів, психотропних речовин і прекурсорів $\epsilon$ неефективною у зв'язку з відсутністю належного контролю за виробництвом, виготовленням, придбанням, зберіганням, відпуском, обліком, перевезенням i пересиланням таких засобів, речовин і прекурсорів.

Мета статті - здійснити аналіз форм діяльності Національної поліції України щодо протидії незаконному обігу наркотичних засобів, психотропних речовин і прекурсорів.

Виклад основного матеріалу. Протидія незаконному обігу наркотичних засобів, психотропних речовин і прекурсорів $\epsilon$ однією із актуальних проблем суспільства. Ї̈̈ ефективність залежить від конкретних форм діяльності одного із суб'єктів протидії незаконному обігу наркотичних засобів, психотропних речовин і прекурсорів - Національної поліції України.

Різні аспекти питання форм діяльності правоохоронних органів досліджувались у наукових працях В.Б. Авер'янова, С.С. Алексієва, Д.М. Бахраха, Ю.П. Битяка, В.В. Богуцького, В.М. Гаращука, А.Ю. Васіной, Н.А. Железняка, С.В. Ківалова, Т.О. Коломоєць, А.Т. Комзюка, О.В. Кузьменко, В.Я. Маліновського, А.Ф. Мельника, В.Я. Настюка, С.М. Павковича, І.Д. Пастуха, В.Д. Сущенка, В.К. Шкарупи тощо. Попри численні наукові розробки, особливості форм діяльності Національної поліції України щодо протидії незаконному обігу наркотичних засобів, психотропних речовин і прекурсорів потребують глибокого аналізу і вивчення. 
Для більш детального розуміння специфіки форм діяльності Національної поліції України щодо забезпечення протидії незаконному обігу наркотичних засобів, психотропних речовин і прекурсорів, на нашу думку, необхідно проаналізувати такі категорії, як «форма» $\mathbf{i}$ «форма діяльності».

Термін «форма» походить від латинського слова "forma", що означає вигляд, зовнішність, устрій, різновид [1, с. 304].

В енциклопедичному словнику Брокгауза і Єфрона форма, як філософське поняття, $є$ способом існування, вираженням і перетворенням змісту [2, с. 273-274].

У великому тлумачному словнику сучасної української мови під редакцією В.Т. Бусела під формою розуміють «обриси, контури, зовнішні межі предмета, що визначають його зовнішній вигляд», а також «внутрішню організацію, спосіб зв'язку елементів у середині системи» [3, c. 612].

В Українській радянській енциклопедії [4, с. 282] форма визначається як спосіб існування змісту, його внутрішня організація та зовнішне вираження. У двох останніх визначеннях поняття форми збігається з поняттям структури.

Ю.П. Битяк та В.М. Гаращук визначають форму як зовнішній вияв конкретних дій, які здійснюються органами держави для реалізації поставлених перед ними задач [5, с. 152]. Саме це визначення пов'язує поняття «форма» $\mathfrak{i}$ «форма діяльності», торкаючись органів державної влади.

С.М. Павкович пропонує наступне визначення форми: «Форма $\epsilon$ зовнішнім вираженням змісту, зовнішньою конфігурацією речі, предмета, його просторовими і часовими межами, форма $\epsilon$ також способом існування матерії у тому разі, коли йдеться про простір і час як атрибути матерії» [6, с. 139].

Як поняття «форма», так i поняття «форма діяльності» мають багатогранний і багатоаспектний характер. Визначаючи форми діяльності, А.Ф. Мельник., О.Ю. Обленський, А.Ю. Васіна в посібнику «Державне управління» [7] вказують, що форми діяльності $\epsilon$ зовнішніми, постійно і типізовано фіксованими проявами практичної активності органів державної влади з формування та реалізації цілей та функцій, а також забезпечення їх власної життєдіяльності [7, с. 142].

Автори підручника «Курс адміністративного права України» В.К. Колпаков, О.В. Кузьменко, І.Д. Пастух, В.Д. Сушенко пропонують під формами діяльності розуміти зовнішнє вираження дій суб'єктів, що ними здійснюються в рамках їх ком- петенції для виконання поставлених задач та тягнуть за собою певні наслідки [8, с. 181].

Стосовно форм діяльності В.Я. Малиновський вказує, що йдеться не про дії суб'єктів, а про їх зовнішнє вираження, оскільки дії залежно від характеру i форми вираження становлять зміст цієї діяльності [9, с. 424].

Н.А. Железняк визначає форми діяльності як однорідні групи зовнішнього вираження діяльності відповідних суб'єктів державної влади з виконання функцій щодо забезпечення реалізації державної правової політики [10, с. 226].

С.М. Павкович у своєму дисертаційному дослідженні «Правові підстави реалізації адміністративних повноважень щодо забезпечення протидії незаконному обігу наркотичних засобів» визначає форми діяльності як зовнішній спосіб вираження, в рамках компетенції повноважних суб'єктів, змісту їх адміністративної діяльності з реалізації поставлених задач, цілей, функцій та призначення у вказаній сфері [6].

Наведені визначення дають можливість визначитись з загальними ознаками форм діяльності Національної поліції України щодо протидії незаконному обігу наркотичних засобів, психотропних речовин і прекурсорів: а) зовнішнє відображення дій органів Національної поліції України; б) реалізація в межах компетенції поліції; в) закріпленість у нормативно-правових актах; г) спрямованість на попередження i усунення негативних чинників, що ускладнюють їх реалізацію.

На підставі аналізу наведених позицій авторів відносно поняття форм діяльності нами запропоновано наступне трактування: форми діяльності Національної поліції України щодо протидії незаконному обігу наркотичних засобів, психотропних речовин і прекурсорів це - зовнішнє вираження дій Національної поліції України, в межах своєї компетенції з питань реалізації завдань і функцій в галузі обігу наркотичних засобів, психотропних речовин і прекурсорів, спрямованих на попередження і усунення негативних чинників, що ускладнюють їх реалізацію.

Юридична літературна з питань класифікації форм діяльності органів влади у сфері протидії незаконному обігу наркотичних засобів, психотропних речовин і прекурсорів дає можливість за ступенем правової регламентації виділити правові та організаційні форми діяльності [5, с. 274; 10 , с. $227 ; 11$, с. 172$]$.

Правові форми виявляються під час реалізації таких функцій, як виявлення та розгляд правопорушень у сфері незаконного обігу наркотичних 
засобів, психотропних речовин i прекурсорів; проведення рейдів та перевірок; проведення спеціальних заходів, спрямованих на попередження, виявлення та розкриття правопорушень, затримання винних осіб та притягнення їх до відповідальності тощо.

С.С. Алексєєв до правових форм відносить правотворчу (діяльність державних органів із надання тим чи іншим правилам загальнообов'язкового значення), правовиконавчу (діяльність державних органів щодо деталізації та конкретизації норм права в індивідуальних актах, які тягнуть за собою виникнення прав та обов'язків певних осіб) та правозабезпечувальну (діяльність державних органів щодо забезпечення як виконання особами покладених на них обов'язків, так і здійснення наданих їм прав) діяльність [12, с. 58].

Окремим видом діяльності в межах виділеної групи, на нашу думку, $\epsilon$ контрольно-наглядова діяльність поліції, яка у сфері протидії незаконному обігу наркотичних засобів, психотропних речовин і прекурсорів має певні особливості. Одним із видів контрольно-наглядової діяльності поліції $\epsilon$ адміністративний нагляд.

Найчастіше під адміністративним наглядом розуміють процес спостереження органу виконавчої влади за дотриманням встановлених правил 3 метою попередження і припинення їх порушень, та застосування заходів впливу до порушника. Вважаємо, що у контексті дослідження зміст контрольної діяльності Національної поліції України у сфері протидії незаконному обігу наркотичних засобів, психотропних речовин і прекурсорів полягає у спостереженні визначеного кола поліцейських (посадових осіб Національної поліції України) у межах наданих їм повноважень за дотриманням обігу наркотичних засобів, психотропних речовин і прекурсорів з метою виявлення та недопущення порушень у цій галузі.

Так, профілактичними заходами $\epsilon$ здійснення адміністративного нагляду за особами, звільненими з місць позбавлення волі. Цей захід провадиться в тому числі і відносно осіб, які відбували покарання в місцях позбавлення волі за кримінальні правопорушення, пов'язані з незаконним обігом наркотичних засобів, психотропних речовин і прекурсорів.

Відповідно до статті 7 Закону України «Про адміністративний нагляд за особами, звільненими з місць позбавлення волі» від 01.12.1994 року осіб, відносно яких встановлено адміністративний нагляд, беруть на облік, фотографують, а у разі необхідності у них беруть відбитки пальців. Пра- цівники поліції зобов'язані систематично контролювати поведінку цих осіб, запобігати порушенням ними публічного порядку та прав інших громадян і припиняти їх, проводити розшук осіб, які уникають адміністративного нагляду.

Правова форма діяльності поліції щодо забезпечення протидії незаконному обігу наркотичних засобів, психотропних речовин та прекурсорів - це специфічна, однорідна за своїми ознаками діяльність, яка здійснюється у точній та неухильній відповідності до вимог норм антинаркотичного законодавства України, результати якої тягнуть певні юридично значущі наслідки [6, с. 143].

Ознаками правової форми адміністративної діяльності поліції $\epsilon$ те, що ця форма має державно-владний, виконавчо-розпорядчий, підзаконний характер управлінських повноважень суб'єкта, уповноваженого законодавцем на вирішення різноманітних завдань у сфері організації протидії незаконному обігу наркотичних засобів, психотропних речовин, їх аналогів та прекурсорів. Саме через використання правової форми практично досягається здійснення задач, що стоять перед Національною поліцією України як одного з суб'єктів протидії незаконному обігу наркотичних засобів, психотропних речовин і прекурсорів.

Крім правової форми діяльності поліції, $\epsilon$ й організаційна форма, яка не потребує повного й суворого юридичного оформлення, не пов'язана з виконанням юридично значущих дій, тобто не тягне за собою правових наслідків. Але вказаний факт не означає, що така діяльність не регулюється нормами права.

Організаційні форми можуть як доповнювати правові форми діяльності, так і мати певне самостійне значення, що значною мірою впливає на можливість виокремлення тієї чи іншої форми.

Організаційні форми $\epsilon$ необхідними елементами діяльності Національної поліції України у сфері протидії незаконному обігу наркотичних засобів, психотропних речовин та прекурсорів та мають на меті забезпечення діяльності суб' $\epsilon$ тів протидії незаконному обігу наркотичних засобів, психотропних речовин і прекурсорів. Так, проведення інформаційних зустрічей із населенням з питань роз'яснення антинаркотичного законодавства належить до цієї форми, підготовка та проведення нарад, семінарів, круглих столів, розповсюдження передового досвіду тощо.

Застосування організаційної форми саме в цій галузі реалізується з метою формування у громадськості позитивного іміджу працівника поліції, уявлення про державну політику у сфері 
обігу наркотичних засобів, психотропних речовин та прекурсорів, протидії їх незаконному обігу.

Висновки. Аналіз форм діяльності Національної поліції України щодо протидії незаконному обігу наркотичних засобів, психотропних речовин і прекурсорів дає можливість визначити, що:

1) ознаками форм діяльності Національної поліції України є: а) зовнішнє відображення дій органів Національної поліції України; б) реалізація в межах компетенції поліції; в) закріпленість у нормативно-правових актах; г) спрямованість на попередження i усунення негативних чинників, що ускладнюють їх реалізацію.

2) форми діяльності Національної поліції України щодо протидії незаконному обігу наркотичних засобів, психотропних речовин і прекурсорів це зовнішнє вираження дій Національної поліції України в межах своєї компетенції з питань реалізації завдань і функцій в галузі обігу наркотичних засобів, психотропних речовин і прекурсорів, спрямованих на попередження і усунення негативних чинників, що ускладнюють їх реалізацію.

\section{Література}

1. Форма. Юридична енциклопедія : [y 6 т.] / ред. кол. Ю. С. Шемшученко [та ін.]. Київ : Українська енциклопедія ім. М.П. Бажана, 2004. Т. 6 : Т-Я. 768 с.

2. Энциклопедический словарь: в 86 т. под ред. И.Е. Андреевского, К.К. Арсеньева, Ф.Ф. Петрушевского. Изд. : Ф.А. Брокгауз [Лейпциг], И.А. Ефрон [Санкт-Петербург]. Санкт-Петербург : Семеновская ТипоЛитография И.А. Ефрона, 1890-1907. Т. 36. 1902. 478 c.

3. Форма. Великий тлумачний словник сучасної української мови (з дод. і допов.) / уклад. і гол. ред. В. Т. Бусел. 5-те вид. Київ ; Ірпінь : Перун, 2005. URL: http://slovopedia.org.ua./93/53412/1010103. html

4. Українська радянська енциклопедія: у 12 т. 2-е вид. Київ : Головна редакція Української радянської енциклопедії. Т 4. 1979. 558 с.
5. Адміністративне право : підруч. Ю.П. Битяк (кер. авт. кол.), В.М. Гаращук, В.В. Богуцький та ін.; за заг. ред. Ю.П. Битяка, В.М. Гаращука, В.В. Зуй. 2-ге вид., переробл. та допов. Харків : Право, 2013. $656 \mathrm{c}$.

6. Павкович С.М. Правові підстави реалізації адміністративних повноважень щодо забезпечення протидії незаконному обігу наркотичних засобів : дис. канд. юрид. наук. Одеса : ОДУВС. 2019. 236с.

7. Державне управління : підручник А.Ф. Мельник., О.Ю. Обленський, А.Ю. Васіна ; за ред. А.Ф. Мельник. Київ : Знання, 2009. 582 с.

8. Курс адміністративного права України : підруч. [В.К. Колпаков, О.В. Кузьменко, І.Д. Пастух, В.Д. Сушенко та ін.] ; за ред. В.В. Коваленка. Київ : Юрінком Інтер, 2012. 808 с.

9. Малиновський В.Я. Державне управління : навч. посіб. 2-ге вид, допов. та перероб. Київ : Атіка, 2003. 576 с.

10. Железняк Н.А. Правові та організаційні форми діяльності Міністерства юстиції України у здійсненні державної правової політики (теоретичні та практичні питання). Наукові записки. 2001. № 19. С. 226-231.

11. Адміністративне право України : підруч. за заг. ред. С.В. Ківалова. Одеса : Юрид. л-ра, 2003. 896 C.

12. Алексеев С.С. Проблемы теории права : курс лекций: в 2 т. Свердловск : Изд-во Свердлов. юрид. ин-та, 1972. Т.1. 1972. 396 с.

Ярмакі Х. П., доктор юридичних наук, професор, професор кафедри адміністративного права та адміністративного процесу Одеського державного університету внутрішніх справ

Tрuгуб C. M., аспірант

Одеського державного університету внутрішніх справ 